\title{
THE PORTRAYAL OF MORAL EVALUATION IN GREEK POETRY
}

Anyone who has read my book Greek Popular Morality in the Time of Plato and Aristotle (Oxford 1974) (hereafter 'GPM') and has also read Professor A. W. H. Adkins' book Merit and Responsibility (Oxford I960) ('MER') ${ }^{1}$ will have noticed that the two books differ substantially in their approach to the history of Greek moral values and in some of the conclusions which they reach. Adkins' critical review of GPM, entitled 'Problems in Greek Popular Morality', CPh lxxiii (1978) I43-58 ('Problems'), explains very clearly why he finds GPM in many respects inadequate or misleading, and it has greatly helped me to understand my own disquiet at the infuence exercised by the presuppositions, methods and conclusions of $M E R$. My purpose in this paper is not to offer a review of $M E R$ twenty years too late, nor to attempt a rebuttal, point by point, of the criticisms of GPM contained in Problems, ${ }^{2}$ but to examine one major issue: how should the portrayal of moral evaluation on the tragic stage or in epic narrative be used as evidence for the history of Greek moral values?

A very important proposition is stated in $M E R$ 127: 'A drama is a practical work; it involves action. People appear on the stage and behave as they do in real life.' With this proposition I agree, subject to three provisos, of which one limits its application and two amplify it. The limiting proviso is obvious. No one, I imagine, would contend that people on stage always and necessarily 'behave as they do in real life', for they sometimes behave in a demonic way which is rare in life, and they commonly organise, intellectualise and articulate the expression of their emotions unrealistically. Since, however, there are passages which become wholly intelligible on the hypothesis that the poet is aiming at realistic portrayal, that hypothesis deserves to be considered as a possible explanation of any passage. The amplifications of Adkins' proposition are more important. First, there is no reason to confine the proposition to drama, excluding epic narrative, the other main genre of Greek representational poetry. Secondly, there is also no reason to exclude linguistic behaviour from the category 'behaviour'. A word is indeed 'a tool with uses' $\left(M P V_{4}\right)$; its uses are heterogeneous, and one of them is the shaping of the personal relationship between speaker and hearer.

What are the distinctive features of linguistic behaviour in respect of moral evaluation? The answer offered by $M E R$ seems to be made up of four ingredients.

(I) 'Any word of general commendation will, in any society, be applied not at random but to persons or events possessing certain characteristics' ( $M E R$ S ). It is conceded (ibid.) that evaluative language 'possesses another element-whose nature it is unnecessary to discuss here-which is peculiar to itself', a concession which leaves open the possibility that this 'peculiar element' may seem to some of us the most important.

(II) Some evaluative words are so 'powerful' (e.g. $M E R$ I 56, I 73, I 86, 254, 268, 282) that they can not only 'restrain' violent or oppressive action (e.g. $\left.M \& R{ }_{39}, H V 4\right)^{3}$ but even 'end an argument' (e.g. MER I 84 f.).

(III) The utterance of an evaluative word can also constitute the 'solution' of a 'problem' (e.g. $M E R$ I52, I75, I85).

(IV) Tojudge from the number of well-known passages which have a bearing on the history

\footnotetext{
1 I refer also to Moral and Political Values in Ancient Greece (London 1972) ('MPV') and 'Homeric Values and Homeric Society', JHS xci (1971) I-I4 ('HV').

2 I find I disagree with Adkins' interpretation of practically all the individual passages mentioned in Problems; an important exception is his correction of my oversight in discussing Xen. Hell. ii 4.40 f. (GPM 67, Problems I 54).
}

3 A. A. Long, 'Morals and Values in Homer', JHS xc (I970) I2I-39, contains much valuable criticism of $M E R$. At one point ( 127 ) Long refers to 'the poverty of Homeric restraints upon the agathos'. Adkins ( $H V$ 9) says "I take it that "restraints upon" means "sufficiently powerful ethical language to restrain", '. $M E R$ I 52,210 , 254 furnish other examples of the transformation of moral issues into linguistic terms. 
of Greek morality but are not mentioned in $M E R$, Adkins' argument seems to presuppose that only the presence of one of the limited number of words which he classifies as commendatory or disapproving identifies an utterance as morally evaluative.

I propose to argue that $(\mathrm{I})$ is quite inadequate as a statement about evaluative utterance; that (II) is true only in certain senses which contribute nothing to the argument of $M \& R$; that (III) is untrue; and that (IV) imposes a crippling constraint on investigation of the history of values. ${ }^{4}$

With regard to (I), it may be agreed without more ado that evaluative words are not applied 'at random' - we are, after all, concerned with a form of interactive behaviour which merits the label 'language'--but 'possessing certain characteristics' is not the only alternative. Philosophers have had a great deal to say about the difference between evaluative and non-evaluative language, but one does not need to be a philosopher to observe the most striking difference. If I say 'There's a cat in my garden', the chances are that you will believe that there is a cat in my garden. If I add 'It's a horrible cat', you are more likely simply to 'register' the addition than to believe or disbelieve it, aware that the cat may possess characteristics which you too would call 'horrible' but may perhaps not. I have disclosed something about my own emotional attitude to the cat, but nothing for sure about the cat, nor even anything for sure about the characteristics which I think I discern in it. The more general a term of commendation or disapproval, the less the things to which it is applied have in common. What is common to many speech-events containing the attribution or predication of a general evaluative term is the disclosure of a favourable or unfavourable reaction on the part of the speaker. At the same time there are circumstances in which the precise grounds of the reaction are understood, e.g. when the predication of 'good' in English communicates the fact that meat has not begun to decompose or that a baby does not cry at night. ${ }^{5}$ In other circumstances, the information-content of an evaluative word is zero, as when a union describes its pay-claim as 'just' and the employer describes his offer as 'fair' and 'reasonable'. In others again, a speaker uses an evaluative word not to disclose or express a reaction of his own but simply because it is the most familiar evaluation in his own ambience. He may speak ironically or conventionally; and often the hearer does not know whether or not the evaluation contained in the speaker's words is shared by the speaker himself. In all cases we have to interpret evaluative language as contributing something to the construction of a relationship between speaker and hearer.

For example, $\mathrm{Od} . \mathrm{xv} 323 \mathrm{f}$, where the term á $\gamma a \theta 0 i$ is contrasted with 'inferiors' and denotes the socially dominant class, is of considerable importance to Adkins' argument ( $M E R \quad 32 \mathrm{f}$.) about the 'world-view' implicit in Homeric terms of evaluation:

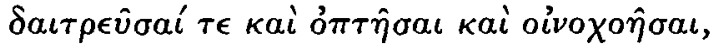

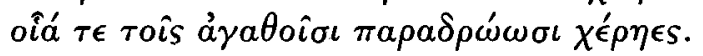

However, Odysseus is speaking here in the role of a labourer looking for work, anxious to serve and to please, and his ingratiating evaluation of himself among $\chi \epsilon \in \eta \eta \epsilon$ and of his potential employers as áyatoí suits the role very well. He is not making a considered sociological statement, but conveying an impression of his own attitude, and the passage does not justify insistence on interpretation of áratós as social in other contexts. Od. xvii $322 \mathrm{f}$. exemplifies a quite different function of evaluation. Eumaios, commenting sadly on the neglect of the old dog by the slave-women of the household, says that servants do not do évaíoura when there is no master to compel them, and he ends with the gnome

${ }^{4}$ Hugh Lloyd-Jones, The Justice of Zeus (Berkeley/ L.A./London 197I) 6 lays proper emphasis on $\mathrm{Il}$. xvi $384-92$ (Zeus sends heavy rain when he is angered by the 'crooked judgments' of men), a passage not mentioned in $M E R$. See below for other instances.

5 Problems I 53 points out that 'such usages do not abolish the possibility that there exists a usage of "good" where the class is no narrower than "human being". True, but in what circumstances do we hear the word 'good' so used? Rarely, if ever, in my experience, outside discussions concerned with ethical theory; and is nothing to be learned from that fact? 


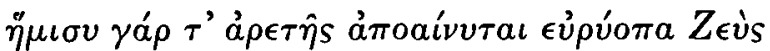

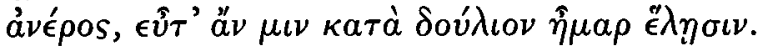

Pl. Leg. 777a, quoting the passage, writes $\tau \epsilon$ vóov for $\tau^{\prime}$ á $\rho \epsilon \tau \hat{\eta} s .{ }^{6}$ Adkins (MER 83 n. 28), while accepting $\tau$ ' $\dot{\alpha} \rho \epsilon \tau \hat{\eta} s$ as the earlier text, 'cannot agree . . . that arete here makes any real sense'; 'in view of the very different qualities expected from men and women in Homer, the loss of arete has very different implications in men and in women, and the transitions in thought are thus difficult'. But there is no difficulty if we suppose that Eumaios' gnome proceeds from the reflection that enslavement diminishes in anyone, of either sex and any age, the capacity to behave in ways which elicit approval and admiration.

These considerations have a bearing on the interpretation of the expression $\alpha^{\prime} \gamma a \theta$ ós $\pi \epsilon \rho{ }^{3} \omega^{\prime} \nu$, which occurs six times in the Iliad, viz.

(a) i 13 I f. (Agamemnon to Achilles)

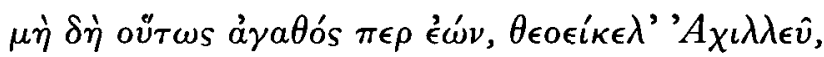
$\kappa \lambda \epsilon ́ \pi \tau \epsilon \nu o ́ \omega$.

(b) i 275 (Nestor to Agamemnon)

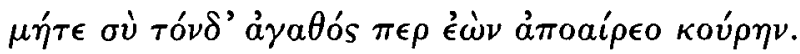

(c) ix $626 \mathrm{f}$. (Ajax to Odysseus)

$\dot{a} \pi \alpha \gamma \gamma \epsilon \hat{\imath} \lambda \alpha \iota \delta \dot{\epsilon} \tau \alpha ́ \chi \iota \sigma \tau \alpha$,

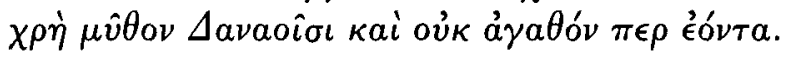

(d) xv i 85 f. (Poseidon to Iris, about Zeus)

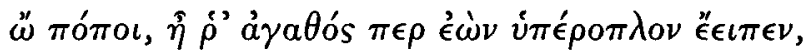

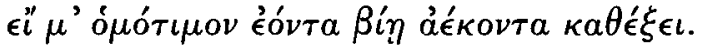

(e) xix iss f. (Odysseus to Achilles)

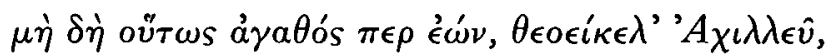

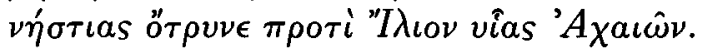

(f) xxiv 53 (Apollo to the gods, about Achilles)

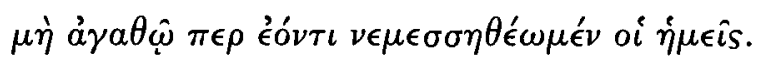

Adkins discusses (a), (b) and (f) in $M E R 37 \mathrm{f}$ and (d) in $H V$ I 3 . He argues in the case of (b) that 'an agathos might well do this' (sc. seize Briseis) 'without ceasing to be an agathos, and indeed derives a claim to do it from the fact that he is an agathos', and in the case of ( $\mathrm{f}$ ) 'The gods do not approve of Achilles' action' (sic; some of them do) 'but clearly the fact that he is agathos gives him a strong claim against gods and men to be allowed to do it'. Adkins alludes to (a), without quoting it, and says that Agamemnon 'complains of Achilles' claims qua warrior and hence agathos' but 'has no higher standards to which he can appeal'. We are encouraged to infer that Achilles as 'an agathos' has a 'claim' to be deceitful. But does Agamemnon really not intend to evoke any sympathetic indignation from the assembled Grecks? If it is possible to contrast a 'good agathos' with a 'bad agathos' - and Adkins recognises that it is, in saying 'the gods do not approve' of Achilles' treatment of Hektor's corpse-then a criterion of evaluation, not necessarily 'higher' or 'lower' than social and military deference, but certainly in conflict with it, is operative.

${ }^{6}$ Cf. J. Labarbe, L'Homère de Platon (Liége 1949) 249-54 and G. Lohse, Helikon v (196s) 289-9I. Their discussions, however, take insufficient account of the fact that Leg. $776 \mathrm{c}-778 \mathrm{a}$ concerns the treatment of slaves by their masters, a matter to which the antithesis between brutal conditioning and rational persuasion is

highly relevant. vóou suits the context in Plato better than $\dot{\alpha} \rho \epsilon \tau \hat{\eta} s ;$ indeed, after the admission in $776 \mathrm{~d}$ that

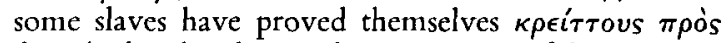
$\dot{\alpha} \rho \epsilon \tau \eta^{\prime}$ than brothers and sons, citation of the Homeric passage in the form in which our Homer texts have it would have been irrational. 
In five of the six passages cited above the point of $\dot{a} \gamma a \theta o^{\prime} s \epsilon \rho \stackrel{\epsilon}{\epsilon}^{\prime} \omega_{\nu}$ is incompatibility between normally evoking a favourable evaluation (from the speaker, among others) and on the occasion of the utterance doing or proposing to do something which evokes an unfavourable evaluation from the same speaker. The conciliatory tone of $(b)$ and (e) is clear. ${ }^{7}$ (a), though it

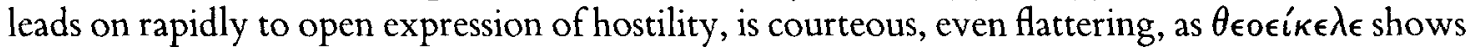
(and if $\theta \epsilon o \epsilon i \kappa \epsilon \lambda \epsilon$ is ironic, so might áyatós be); both (a) and (d) have something in common with the angry 'With respect, Sir, ...' which one may hear at a committee meeting. Apollo in (f), trying to win over the gods, ${ }^{8}$ implies that while their evaluation of Achilles is normally favourable, in this instance Achilles may incur a displeasure in conflict with that evaluation. The point of $(c)$ is the exact converse: incompatibility between the unwelcome character of news and promptitude in transmitting it. (c) is the only one of the six passages in which the objective ground of the evaluation can be stated; in the other five the explicit recognition of the person addressed or spoken about as áyatós serves to define the speaker's standpoint and construct a certain relationship between him and his hearer(s). Many of us have heard (e.g.) 'I am sure Mr X would be an excellent chairman, but ...' uttered by a speaker who was convinced that $\mathrm{Mr} \mathrm{X}$ would be a very bad chairman; and if it is objected that it is frivolous and misleading to compare Greek gods and heroes with modern committee-members, I must reply that I am comparing modern conventions which in some circumstances govern the expression of very strong feelings with the portrayal of the expression of strong feelings by an ancient poet who was patently sensitive to social convention.

The importance of interpreting an evaluation in terms of the function of the entire utterance which contains it is illustrated by certain passages concerning the suitors in the Odyssey. In $O d$. xxiii i2 I f. Odysseus tells Telemachos

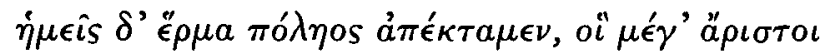

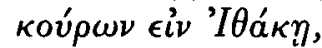

and in xxiv 429 Eupeithes, father of Antinoos, inciting the kinsmen of the suitors to vengeance, says that Odysseus has slain $K \epsilon \phi a \lambda \lambda \eta^{\prime} \nu \omega \nu$ oै $\chi$ ' á $i^{\prime} \sigma \tau o v s$. Medon and Halitherses attempt to persuade them not to seek vengeance (439-62), the former on prudential grounds and the latter on moral grounds (epic poets, like dramatists, attach some importance to symmetry and eschew the portrayal of two speakers making the same point). $M E R 243$ n. 24 says: 'Stress the crimes of the suitors as they will, [they] can do nothing to outbid Eupeithes' evaluation of the matter.' The terminology of games ('outbid'; $c f$. on 'trumping' below) distracts the reader from the essential point. Eupeithes is a bereaved father; naturally he wants revenge, he wants to persuade others to join him in seeking revenge, and therefore he speaks of the dead suitors as good men and of their killing as a crime. In xxiii I 2 f. Odysseus is deeply apprehensive about the consequences of his victory: the killing of even one man who has no followers causes the murderer to flee into exile, 'and we have killed the bulwark of the city.... When we want to assess a danger on the principle of 'the worst case' and to impress on someone else its magnitude and the urgency of providing against it, we not uncommonly look at the situation through the eyes of those from whom the danger threatens. In a different context, Odysseus denies the á $\rho \epsilon \tau \eta$ ' of the suitors, xviii 383: provoked by the insults of Eurymachos, Odysseus tells him

\footnotetext{
${ }^{7}$ Martin Hoffmann, Die ethische Terminologie bei Homer, Hesiod und den alten Elegikern und Iambographen. i. Homer (Diss. Tübingen 1914) $74-8$, though he anticipates Adkins in his view of the conduct expected of someone valued as áratós, concedes (76) that in Il. i

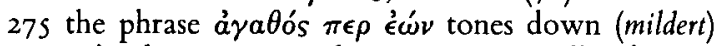
Nestor's admonition. In this connection, Adkins' question ( $H V V_{13}$ ) 'Why does Poseidon say that Iris' words

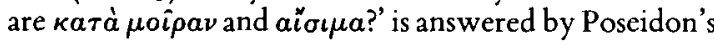

own words in 207: she has shown forbearance and diplomatic skill in suggesting he might reconsider his answer to Zeus.

${ }^{8}$ The question posed in $H V$ I I, 'Now why does Hera take this very different view?' is answered by xxiv $25-30$. For the reason given there, she wishes to cause the gods not to restrain Achilles, and she judges that the best way to do that is to try to implant in them a feeling which may swamp the feeling evoked by Apollo. 


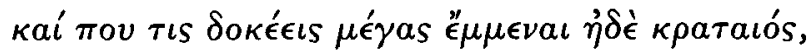

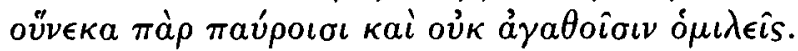

$\pi a v$ po $\sigma \iota$ rhetorically plays down the number of the suitors (in other contexts the number seems formidably large to Odysseus) to emphasise the point, 'a big fish in a little pond', and however

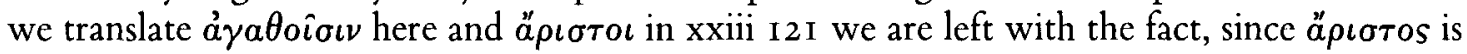
unquestionably the superlative of $\dot{a} \gamma a \theta$ ós, that contradictory evaluations of the same people are elicited from the same speaker by different moods and purposes.

When Halitherses is trying to dissuade the kinsmen of the suitors from seeking revenge, he tells them (xxiv $455^{-7}$ )

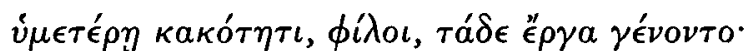

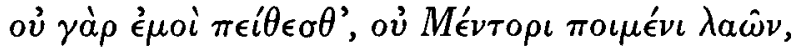

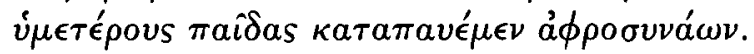

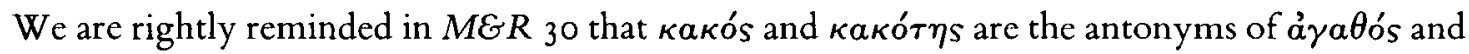
$a \rho \epsilon \tau \dot{\eta}$. The implication of the passage is that the kinsmen were какоi because they did not prevent the suitors from committing the acts which Halitherses regards as reasons for not avenging the suitors' death. In view of Adkins' statements (MER 57 n. 2) that 'kakos and kakotes in Homer normally decry failure' and 'Homer knows only one sense of kakotes', it may be that he

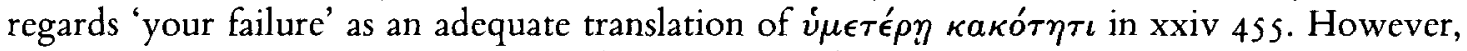
'failure (to . . .)' is ambiguous in English, covering both an unsuccessful attempt and the absence of an attempt. The former is irrelevant here; in Halitherses' view, the какó $\tau \eta s$ of the kinsmen lay in their rejection of-or indifference to-his advice, not in the collapse of any earnest attempts at restraint on their part (he himself is the one who has 'failed' in that sense), nor in the calamity which is now the end-product of their rejection of advice.

In $\mathrm{Od}$. xxi, when the disguised Odysseus has asked if he may try the great bow, Antinoos threatens him (288-3 ro). Penelope reproaches Antinoos, saying ( 3 I $2 \mathrm{f}$.) that it is not $\kappa a \lambda{ }^{\prime} \nu$ or $\delta i$ í $\iota$ ov to abuse her son's guest. Eurymachos explains that if by chance the beggar can draw the bow when the suitors cannot they will be regarded as inferior and suffer $\epsilon^{\prime} \lambda \epsilon^{\prime} \gamma \chi \epsilon a(323-9)$. Penelope replies that men who, like the suitors, dishonour the house of an $\dot{\alpha} \nu \grave{\eta} \rho \dot{\alpha} \rho \iota \sigma \tau \epsilon \dot{v} s$ by their behaviour cannot in any case expect to be $\epsilon \dot{v} \kappa \lambda \epsilon \eta^{\prime} s$; why then do they treat failure to draw the bow as $\dot{\epsilon} \lambda \epsilon^{\prime} \gamma \chi \epsilon a(33 \mathrm{I}-3)$ ? She implies that their behaviour merits such great reproach that by comparison the matter of the bow is trivial and irrelevant. Adkins says ( $M E R$ 39) that such an implied use of the word "̈ $\lambda \epsilon \gamma \chi 0 S$ is 'impossible'; 'she (or rather the poet) attempts a use of language, a "persuasive definition", which, if accepted, would effectively restrain the suitors. ${ }^{9}$ The definition cannot succeed'. There is certainly one sense in which Penelope 'cannot succeed' in filling the suitors with effective remorse: if she did, the rest of the Odyssey would be a flop; the story, after all, is about the triumph of a hero in disguise, against heavy odds, over offenders who did not repent and therefore could not, without spoiling the story, be portrayed as 'accepting' any reproach, whatever words were cast at them. But the somewhat hyperbolic description ${ }^{10}$ of Penelope's use of the word "̈ $\lambda \epsilon \gamma \chi 0 s$ as 'impossible' presumably means that Penclope is mistaken if she thinks the behaviour of the suitors likely to incur adverse evaluation from anyone other than those materially affected by it (e.g. Odysseus, Telemachos, Eumaios) or committed (as Athena is) to support of Odysseus. But what evaluation of such behaviour does the poet expect from his hearers? Does nothing in it merit our reproach, indignation or contempt except the suitors' imprudence in assuming that Odysseus was dead and their inability to save their own lives? And how is the 'impossibility' of 'є $\lambda \epsilon \gamma \chi \chi \chi^{\circ}$ to be reconciled with Halitherses' attitude in xxiv 455?

${ }^{9}$ An example of a persuasive definition may be found (as remarked in Problems I 55) in GPM 43, where I am trying to persuade the reader to define a certain term in a certain way. What have come to be called

'persuasive definitions' in common practice are not definitions but applications.

${ }^{10}$ Cf. Long (n. 3) 126 n. I6. 
Curiously enough, 'cannot', which in this connection provokes objection, in another connection demands the assent which we give to a banal truism. In Il. viii I $37-56$ Nestor advises Diomedes to retreat; Diomedes says that he is intolerably distressed by the thought that Hektor will boast that Diomedes has fled from him in fear; and Nestor assures him that if Hektor says any such thing, the Trojans and the widows of Trojans killed by Diomedes will know better. Adkins comments ( $M E R$ 49) that 'Nestor cannot say, "Don't worry. It isn't true", , from which he deduces that 'facts are of much less importance than appearances'. Certainly Nestor cannot usefully or relevantly say 'Don't worry. It isn't true', because Diomedes already knows it isn't true, and what 'worries' him is his reputation. 'Don't worry. It isn't true' would be a fatuous reply, not only in archaic Greece, but nowadays too, or at any time and place; $I l$. viii I37-56 therefore tells us nothing whatever about any distinctive features of early Greek morality.

Consideration of the 'effectiveness' of Penelope's words has brought us into the area of what I have listed as Adkins' principle (II), the treatment of certain words as intrinsically 'powerful'. For a given individual, there may well be words which he is inclined to use only when strongly moved and words which, when they are used of him by others, particularly gratify him (e.g. 'elegant', 'professional') or anger him (e.g. 'disingenuous', 'fat'). In this sense of 'power', each of us has his private hierarchy of words. It so happens that within twelve months I have heard '. . . is an absolute shit' predicated (i) by $A$ of $B$, (ii) by $C$ of $D$ and (iii) by E of $F$. The forthright word could fairly claim to be among the most 'powerful' (and least ambiguous) expressions of moral disapproval in modern spoken English; I myself would not use it with a second-person subject, for fear of being struck or damaging a relationship irreparably. The intended information-content was different in each case, and the application of the same predicate to the three subjects $B, D$ and $F$ was not determined by their possession of what a third party could perceive to be common characteristics. (i) was more or less jocular; A communicated the opinion that $\mathrm{B}$, whom in fact he likes and respects (they are both senior military commanders), is a strict disciplinarian, and in order to communicate this he spoke (using 's', while C and E used 'is') from the standpoint of someone adversely affected by B's insistence on discipline. (ii) and (iii) were far from jocular. C's evaluation of D was generated by his conviction that $\mathrm{D}$ had acted in a ruthlessly selfish manner contrary to the interests of the institution which it is C's job to serve, and $\mathrm{E}$ 's evaluation of $\mathrm{F}$ by firm evidence that $\mathrm{F}$ is untruthful and unreliable. $\mathrm{C}$ is an irascible man who has ready recourse to strong and vulgar language, but $E$ had never before, in my long acquaintance with him, voiced an uncharitable judgment or expressed himself intemperately; hence for me as hearer the moral impact of (iii) was far greater than that of (i) or (ii). The communication of information, with incidental revelation of the speaker's own standpoint, was a more important determinant of (i) than of (ii) or (iii). The intention to influence the hearer was prominent in (ii), negligible in (i) and subordinate in (iii). The main function of utterance in (ii) and (iii) was to alleviate the physical discomfort created in the speaker by anger. ${ }^{11}$ The power of the term 'absolute shit' to affect my own evaluation of $B, D$ and $F$ was derived from my knowledge of the character and practice of the speaker in each case and from my understanding of the purpose of the utterance in its whole context.

My intention in citing these examples is not to labour the point, familiar to everyone, that the way one talks on a particular occasion depends in part on one's social and personal relations with the hearer (this consideration is most obviously relevant to the interpretation of comic and Platonic dialogue, and even sometimes to its textual criticism, e.g. Pl. Gorg. 497a). What I deduce from the examples is that if we are to talk about the power of words in the interactions portrayed by poets we must start from careful observation of how words are actually used in the interactions of our daily lives. Neither Greek nor English is a game played under rules which define certain words as trumps. Suppose, in the examples cited, that I had contended that B is a kindly and lenient man, that $\mathrm{D}$ is notably altruistic, and that $\mathrm{F}$ is invariably truthful. The

11 This is what I meant by my reference in GPM so to 'finding the right words' and to 'the expressive aspect 
contrary evaluations made by $\mathrm{A}, \mathrm{C}$ and $\mathrm{E}$ might well have started an argument, but are there any circumstances in which they could have ended an argument, and, if so, how? What docs end an argument? I stop ${ }^{12}$ arguing with someone (i) when I judge it very unlikely that he will change his mind; or (ii) when he betrays emotion and I fear his hostility or would be sorry to impair friendship with him; or (iii) when he is someone whose judgment and sensitivity I respect so highly that my confidence is shaken by the bare fact of his disagreement and I need to think further; or (iv) when I am struck by second thoughts for some other reason; or (v) when I get bored with the argument; or, of coursc, (vi) an argument may end when one of us has convinced the other by reasoning that the particular instance about which we are arguing exemplifics a general rule on which we agree. The overt evaluative signals used by my opponent - language, silences, hesitations, facial expressions, slight bodily movements may bring about (ii) and may have a bearing on (i) and (iii), but not on (iv) or (v). They may help to stimulate effort towards (vi), but cannot of themselves accomplish it, because what matters in (vi) is the movement of our thought about the situation under discussion, not any particular signals in which we expose our thought.

Let us turn now to three of the examples in which Adkins discerns 'trumping power' in words; all three concern the killing of Agamemnon by Klytaimestra or her killing by Orestes.

(a) S. El. $558-60$ (MER i $56, c f$. I 85$)$. Klytaimestra has argued ( 5 I6-5 I, especially 528,538 , 550 f.) that her killing of Agamemnon was justified retaliation for the sacrifice of Iphigencia. Elcktra retorts

$$
\begin{aligned}
& \tau i \dot{S} \ddot{a} \nu
\end{aligned}
$$

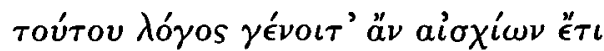

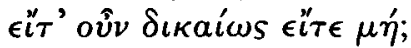

Adkins comments: 'To say that an action is aischron is to play the ace of trumps; to justify performing it, one cannot press the claim that it is dikaion, for this is of less importance, but must maintain that it is in fact not aischron after all.' Why then, after, 'playing the ace of trumps', does Elektra go on to argue (i) $560-79$, that the killing of Agamemnon was not in fact justifiable retaliation, (ii) $580-3$, that by giving precedence to the principle of retaliation Klytaimestra is imprudently endangering her own future, (iii) $584-94$, that Klytaimestra's marrying Aigisthos and driving out her own children is behaviour going beyond anything which could be represented as justifiable retaliation, and after (iv) 595-605, an expression of hatred and of self-pity, declare (v) 605-9, 616-2 I, that her own behaviour is indeed ai $\alpha \chi \rho o ́ s$ and ávaı $\delta$ '́s but forced upon her? Why does the chorus-leader (6 I o f.) remark on Elektra's vehemence but admit to bewilderment over the rights and wrongs of the argument? And why is Klytaimestra, so far from being silenced by Elektra's 'ace', moved to voluble anger? That last question, at any rate, is answered easily enough. Depicting two enemies in irreconcilable conflict (the irreconcilability is a datum of the legend) Sophokles has constructed an $a \dot{\gamma} \omega \dot{\omega} \nu$ of familiar typc, comprising one long speech on either side. He has represented Elektra as trying to hurt Klytaimestra as much as

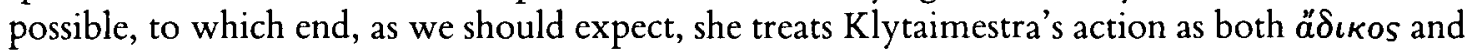
aioxpós. It would have been an aesthetic error to make the first speaker embark on a systematic refutation of the second speaker's rebuttal of the first speaker's case.

(b) E. Or. 194 (MER I 85). Elektra's despairing utterance (19I-3)

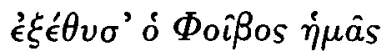

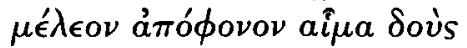

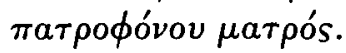

provokes from the chorus the comment $\delta i^{\prime} \kappa a \mu^{\prime} \epsilon^{\prime}$, to which Elektra retorts $\kappa a \lambda \hat{\omega} s \delta^{\prime}$ ov and goes

\footnotetext{
12 With reference to a stylistic habit which has on at least one occasion given rise to uncertainty (Problems 149), it should be said that Dover borrows from Locke

the use of the first-person singular pronoun, with present, future and conditional tenses, in a generalising sense.
} 
on to apostrophise her mother. Adkins says, 'Naturally ... this settles the matter, for there is no higher term of value to invoke'. But for whom is anything 'settled' by the words $\kappa a \lambda \hat{\omega} s \delta$ ' ou"? Persistence by the chorus in maintaining that Apollo's verdict was just would spoil the symmetry within the kommos, so we cannot expect to hear more than three syllables from them at this point. A simple 'No, not justly!' from Elektra would be $\psi v$ xpóv. We already know (28, I62-s) what she thinks about the 'justice' of Apollo's verdict, and when the chorus still assert that it was just, what can she do but brush that aside and express, by one of the most general of all evaluative adverbs, her reaction to the limitless suffering, rejection and mortal danger into which she and Orestes have now been cast? (It is worth recalling in this connection that the chorus in E.

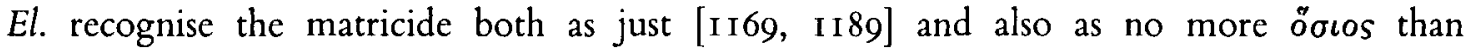
Klytaimestra's own crime [I203 f. I I70]; many an act can be looked at with conflicting emotions which find expression in conflicting evaluations.)

(c) E. El. Ios I-4 (MER I85). After Klytaimestra's speech of self-exculpation (IOII-50), ending with the challenge to Elektra

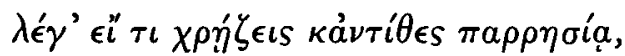

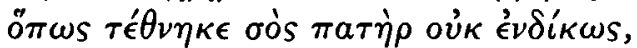

the chorus-leader says

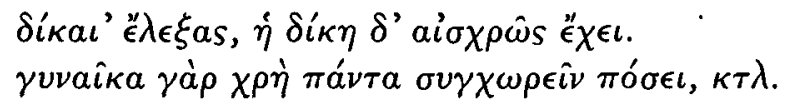

'The judgment, and the result', says Adkins, 'are the same' (sc. as in E. Or. 194?): 'the argument goes no further'. What argument? The issue is between Klytaimestra and Elektra, and that argument goes a great deal further, for Elektra delivers a long riposte (1060-96), ending by picking up Klytaimestra's év $\delta$ íkws:

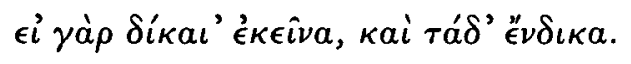

Each participant in the conflict, that is to say, claims to be making a just case, but to Elektra, as in (a) and (b) above, cool assessment of justice is not what matters. It is common for a chorus-leader present during such a conflict to act as 'moderator'. Sometimes he or she expresses carefully-worded impartial approval (e.g. S. Ant. 68 I f., 724 f.) or disapproval (e.g. S. $A j$. I09 I f., I I $8 \mathrm{f}$., OT 404-7), sometimes outright partiality, particularly when the fate of the chorus is part of the story (e.g. E. Supp. 463 f., 5 I I f., Tr. 966-8), but in any event neither participant in the conflict turns it into a three-cornered fight by rebuttal of the chorus-leader's comment. In the present case the chorus-leader sides with Elektra, expressing a preference for a conventional, submissive attitude which would have prevented the tearing-apart of the House of Atreus.

I say 'preference' deliberately, and 'the chorus-leader' and 'Elektra' rather than 'Euripides' no less deliberately, in order to introduce discussion of Adkins' principle (III), neatly exemplified in his view that passages (a)-(c) 'express the solution of the two poets to the problem set by the crime within the family'. It is perfectly true that for a member of the audience properly engaged by what is set before him the questions 'Ought Klytaimestra to have killed Agamemnon? Ought Orestes to have killed Klytaimestra? What would I have done in their position?' fully merit the dignity of the term 'problem', but each of the utterances quoted in (a)-(c), so far from meriting the dignity of 'solution', simply discloses one of the ingredients which constitute the problem. In any case, treatment of a selected utterance by one character in a play as the poet's own voice, without regard for the function of that utterance by that character in that situation, is a throwback to the attempt by a certain Hygiainon (Arist. Rhet. I4I6a28-35) to persuade a jury that the author of Hipp. 6I 2 could not be trusted. At one point (MER i5 I n. I8, on A. Supp. 228-3i) Adkins seems to be affirming Hygiainon's Law: 'Aeschylus himself presumably believed in a post-mortem judgment since, unlike the court-poet Pindar, he had no incentive to produce beliefs which were not his own.' But this is worse than uncritical; it is anti-critical. The 
composition of fiction is no mean incentive to 'produce' beliefs which are not one's own, and it would be sensible to work on the assumption that the dramatist, imitating reality, made people say the kind of thing that people say.

One kind of thing is a generalisation which (in common with its denial) can be supported by examples and is elicited by emotional reaction to an example or by perception of its usefulness as a way of bringing about a desired situation. Unverifiable religious statements are a related genre. Two passages of Homer, bearing upon moral responsibility, require comment in this connection.

(a) Il. iii 164 (Priam to Helen)

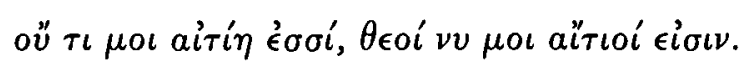

So long as it is believed that some events are determined by the gods, the belief is available for use by anyone who wishes to represent a particular event as so determined. He may, for example, wish, out of kindliness or courtesy, to relieve someone else of guilt or self-reproach. Helen is filled with self-reproach in $I l$. iii, and Priam's gentle forbearance towards her ${ }^{13}$ is a motif which recurs in xxiv 770. The passage does not tell us what the poet, or any actual person, thought about the culpability of Helen, still less what he thought about divine responsibility in general.

(b) In Od. i $32-4$ Zeus, speaking to the gods about the fate of Aigisthos, says

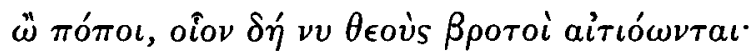

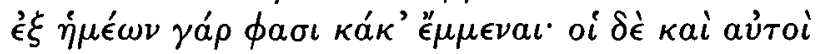

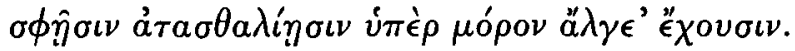

Adkins (MER 24) describes Zeus' words as a 'violent response' to Il. iii I64 and as 'a comment by the poet himself on a contemporary belief. He rightly observes that as a universal statement Zeus' 'response' appears to be refuted by the obstacles which Poseidon is putting in the way of Odysseus' return. He tries to solve this contradiction by suggesting that Zeus is speaking only of those $\kappa a \kappa a ́$ which proceed ultimately from the wrong decisions of mortals, i.e. $\kappa a \kappa a ́$ of the type exemplified by the case of Aigisthos, described in 35-43. I cannot deny the possibility that the poet may have intended his hearers, who will have taken $\kappa \alpha \kappa a ́$ in 33 as a reference to unwelcome happenings in general, to revise their interpretation of the line after hearing $35-43$, but there is a simpler explanation. The essential data are: people believed that some calamities were caused by gods; they also recognised that some were not; and they knew that there is no sure way of deciding whether or not a given calamity has been caused by a god, given that a god can even distort a mortal's thinking and feeling. To these fundamentals must be added a most unusual feature of the case of Aigisthos. ${ }^{14}$ Unlike the sinner who chooses to blame the gods in retrospect for his $\sin$ (and is sometimes right), Aigisthos had actually received in advance from Hermes a perfectly explicit warning of the danger he would face if he killed Agamemnon. This fact makes the exasperation of Zeus pardonable; he speaks under the stress of emotion, for his opening words, $\ddot{\omega} \pi$ ó $\pi$ o oîov $\kappa \tau \lambda$., are an exclamation. When exasperated, we exaggerate, saying (e.g.) 'You never wipe your feet!' rather than 'You sometimes forget to wipe your feet', and Zeus' (untrue) generalisation illustrates normal behaviour.

A comparable situation is portrayed in Il. xxii 490-500, where Andromache, cast into extreme grief and despair by Hektor's death, foresees that if their baby son survives he will endure hardship as an orphan: he will be dependent on the compassion of his dead father's comrades even for a meagre drink, and some other boy whose father is alive will insult him and push him away from the feast. We have no firm evidence for the actual treatment of orphans in early Greece, though we can see what Hesiod preached: Op. 330 classifies offences against orphans with maltreatment of suppliants and guests, abuse of one's parents and adultery with

${ }^{13}$ Cf. Albin Lesky, 'Göttliche und menschliche Motivation im homerischen Epos' (Sitz.Heidelberg 1961.4) 40 .
${ }^{14} \mathrm{~W}$. Jaeger, Scripta Minora (Rome I960) 322 has some interesting remarks on this exceptional feature of the case of Aigisthos. 
one's sister-in-law. Andromache's words are poor evidence. Obviously an orphan, in Greece as clscwhere, was a potential victim of neglect by adults and bullying by another child; and any woman in Andromache's situation is likely to foresee, in the most vivid and concrete terms, continuous and unrelieved realisation of all the worst possibilities. The passage is realistic dramatic portrayal of a despairing imagination at work, not a social worker's report. ${ }^{\mathbf{1 5}}$

One does not need to ask how a widow in Andromache's position in the archaic Greek world would have evaluated the character and behaviour of a man who went out of his way to be kind and helpful to her orphaned son. It is however legitimate curiosity to ask how other people, not bound to her by kinship or any special obligations, would have evaluated such conduct, and also to ask what Greek words the widow would have used in thanking the man to his face or praising him in his absence. It is, of course, possible that she would not have used the commendatory words which are studied in $M E R$. None of those words is used in Od. ii 229-4 I, where Mentor bitterly reproaches the people of Ithake for their ingratitude in allowing the suitors to appropriate the wealth of a kindly king ( $c f$. Athena in $\mathrm{v} 8 \mathrm{ff}$.). That passage might well be among the first to come into the head of anyone considering the history of morality in the Greck world, because the questions it raises are so important. ${ }^{16}$ Why is ingratitude treated as meriting reproach? Is ingratitude towards a kindly king worse than disloyalty to a king who asserts a 'claim' to act 'as an agathos'? By what criteria do subjects evaluate their rulers? Yet another passage, this time from Acschylus, raises, without using words translatable as 'good', 'bad', 'admirable', 'shameful', or the like, a moral question of peculiar importance and interest (except, apparently, to commentators on Aeschylus), Ag. 950-3. Agamemnon tells Klytaimestra to treat Kassandra kindly;

\section{$\tau \dot{o} \nu \kappa \rho \alpha \tau o \hat{v} \nu \tau a \mu a \lambda \theta a \kappa \hat{\omega} s$

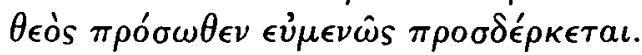

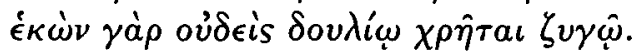

Since it is in Agamemnon's interest to utter a generalisation which, if believed, would tend to the advantage of his concubine, the passage does not tell us what Aeschylus himself thought about $\dot{o}$ $\mu a \lambda \theta a \kappa \hat{\omega} s \kappa \rho a \tau \hat{\omega} \nu$. Nor does it tell us whether we are intended by the poet to regard Agamemnon as a man in whom kindly behaviour towards slaves was a firm principle or as a hypocrite who moralises to his own advantage, for those two alternatives are not exhaustive; he may be a man who, like many of us, is easily induced by perception of advantage or disadvantage to voice a belief which is held by some people and might be true. The only thing unambiguously shown by the passage is that the gencralisation was available in $458 \mathrm{BC}$, and this provokes questions. Why should the gods look with favour on a conqueror who behaves nicely to his captives? Is it an eccentric whim on the part of the gods, which we are prudent to humour, or has a rcligious sanction been created for a mode of behaviour approved by mortals? Why is the fact that no one chooses to be a captive slave a reason for treating such a slave nicely? And how are our answers to these questions to be integrated with all our other evidence for Greck values in the time of Aeschylus?

Enquiry into the values apparently underlying favourable and unfavourable responses to events which have a moral aspect is a much larger task than scrutiny of passages which contain a common evaluative word, and it secms to me that the narrow focus of $M E R$-narrowed even further by casual treatment of $I l$. i I 3 I and omission of (e.g.) Od. xxiv 455 -has resulted in a wholly unconvincing picture of Greck morality. Granted that it is not practicable to be consistent in translating evaluative words from one language into another (and this is so even

15 Yet M. L. West comments on Hes. Op. 330 Another uncommon item. An orphan has to go bcgging ...; see Il. 22.490-9', and W. den Boer, Private Morality in Greece and Rome (Leiden 1979) 38 even turns Andromache's vision into a statement of accomplished fact: "The little Astyanax was banished from the circle of his friends....

${ }^{16}$ Cf. Long (n. 3) 123 n. 8 and J. de Romilly, La Douceur dans la pensée grecque (Paris 1979) $16 \mathrm{f.,} 20 \mathrm{f}$. 
when the two languages concerned are both modern and Western), Adkins' insistence on keeping Greek terms in Greek tempts him on occasion, by importing those terms into the description of situations, ${ }^{17}$ to make what is actually familiar and intelligible sound alien and mysterious. For example, $M E R 238$ says 'Odysseus, having killed the suitors for the sake of his arete, because it would be aischron not to do so . . . I I have always assumed that Odysseus killed the suitors for exactly the reasons for which I would have sought to kill them if I had been Odysseus: they had conspired against my son, pestered my wife and consumed my possessions. ${ }^{18}$ It is obscurantist to imply that Odysseus said to himself: 'My God, I must do something about my arete!'

Adkins' enquiry into the history of Greek moral values was prompted ( $M E R$ I f.) by his observation that in the philosophical writings of Plato and Aristotle comparatively little attention is paid to the problem of moral responsibility, a problem of considerable interest to modern philosophers. He rightly seeks to explain the difference by reference to the moral values and presuppositions which Plato and Aristotle inherited from the culture into which they were born. It may be that it is his philosophical starting-point which predisposes him to treat pre-Platonic non-philosophical writers as if they were struggling towards the analysis, definition and classification of virtues; and, conversely, to treat our own morality as the product of modern philosophy (in particular, of Kantian philosophy; cf. $M E R$ 2, 253).

The notion that our society lacked a moral ingredient until Kant fed it in should not be allowed to pass without scrutiny. I am not thinking simply of the fact that out of those few people who actually study moral philosophy not all find the doctrine of the Categorical Imperative appealing at the time and hardly any recall five years later what it says. A fact of far greater significance is the continuity and wide diffusion of general moral rules which have some degree of superficial affinity with the Categorical Imperative but are much older than Kant. 'Do as you would be done by' is Christian (Mt 7.I2) and pre-Christian; ${ }^{19}$ it is most commonly treated, especially in the upbringing of small children, as a rule of self-regarding prudence. The unconditional claim of duty (to the law of God) ${ }^{20}$ is also Christian, foreshadowed by the pagan gods' unwillingness to tolerate violation of the rights of suppliants. ${ }^{21}$ 'How would you like it if . . ?' is neither prudential nor religious, but an appeal to the imagination and human solidarity; cf. GPM $268-72$.

As for moral responsibility, Kant's attempt at metaphysical level to reconcile freedom of the will with causal determination can fairly be called 'a hopeless failure, as has often been pointed out', ${ }^{22}$ and his statement (Critique of Pure Reason B $582 \mathrm{f}$.) 'although we believe the action to be thus determined, we none the less blame the agent' is false, because we don't. ${ }^{23}$ The question, 'Was this person free to abstain from that action?' is a question which understandably interests philosophers and theologians, ${ }^{24}$ and courts of law often have to pretend that it is answerable, ${ }^{25}$

${ }^{17}$ E.g. $M E R$ I83 (on Agamemnon's quarrel with Achilles), $23 \mathrm{I}$ and 259 (on Socrates) and $M P V$ ss (on Solon). In MPV I 4 I the translation of Thuc. vi 39. I

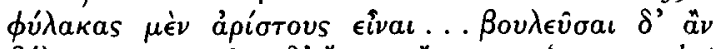

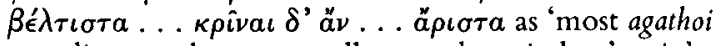
guardians . . . best counsellors ... best judges' might just conceivably be defended by arguing that "be "ू $\rho \iota \sigma \tau o s^{\prime}$ does not have quite the same connotations as

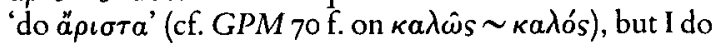
not know how many people would be convinced by such a defence. (I am grateful to Ms Cynthia Farrar for drawing my attention to the example.)

18 R. Pfeiffer, Ausgewählte Schriften (Munich 1960) 17 sees the killing of the suitors as something which the archaic Greek world regarded as 'natural' but which das rechtliche Denken of a later age was not so likely to accept. True, but it is feeling, not thought, which is the point at issue in $M E R 238$.
19 See Albrecht Dihle, Die goldene Regel (Göttingen I962), esp. 96 and IOI.

${ }^{20}$ Keith Ward, The Development of Kant's View of Ethics (Oxford 1972) 167 remarks that Kant produced 'a deeply religious ethics expressed in a radically humanistic terminology'.

21 Cf. Hdt. i I 59.4, discussed by John Gould, JHS xciii (1973) $83 \mathrm{f}$.

22 R. C. S. Walker, Kant (London 1978) I 48.

${ }^{23}$ This is the kind of thing I had in mind when I expressed reservations (GPM 7) about philosophers' assertions about what 'we' say, think or feel.

24 The idea of 'self-damnation' is important to many Christians: cf. $J H S$ xciii (1973) 58 , on modern attitudes to Agamemnon's dilemma.

${ }^{25}$ Punishment without 'blame' is not unknown, and a judicial sentence has several determinants other than the judge's assessment of the defendant's responsibility. 
but in most circumstances we ask a different question, "How difficult was it for this person to abstain from that action?' The answer is commonly determined by our relations with the person whose action we are judging and by the function of the judgment in its practical context. An individual tends to excuse himself (not surprisingly, since he knows how the forces acting on him were experienced, which no one else can know) and those to whom he is bound by affection and loyalty (not unreasonably, for people can be expected to try to divert hostility away from their own ambience). Conversely, he seeks reasons for denying merit to an adversary. The key words are 'I/he/etc. never had a chance' and 'Well, it's easy for you/him/etc.!' In Greek literature, where the possibility of direct intervention by deities in human minds is accepted, the conflict between Hecuba and Helen in E. Tro. 9I4-I032 is paradigmatic (cf. MER I24-7). This conflict is not a seminar on responsibility but $\pi \epsilon \rho i \psi v \chi \hat{\eta} s \hat{a} \gamma \omega \dot{v} v$. Nor did the arguments in it have to wait for the sophistic age, for the same notions operate in epic. Note in particular $I l$. i 178 and 290 f., where Agamemnon decries Achilles' preeminent strength and skill in battle as a gift of the gods and therefore not adequate grounds for a high evaluation of Achilles. When Homer portrays Agamemnon in $\mathrm{Il}$. xix $85-138$ as blaming his treatment of Achilles on distortion of his wits by an external (superhuman) force, and no one contests or comments on the excuse, we recognise a familiar situation: if we are glad to see a quarrel settled, we do not hark back to its origin and dispute the terms in which face is saved, whether we believe them or not ${ }^{26}$ (key-words: 'Something came over me', 'I can't think what made me do it' and 'I wasn't myself at the time').

It may well be thought that the picture I have given of ancient and modern morality is cynical and 'reductionist' in the sense that it reduces morality to politics. I will compound the offence by declaring my conviction that the contrasts commonly drawn between ancient and modern morality lose their appeal when we turn our attention critically to the values implicit in the resolution of everyday dilemmas, and in ordinary conversation, interviews, advertising and press reports of proceedings in local government and the magistrates' courts. My 'reduction', however, does not touch moral philosophy, which is legitimately and interestingly concerned to investigate the relation between morality and reason. ${ }^{27}$ According to his definition of morality, the philosopher must abstract the moral aspect or ingredient from actions which will not necessarily seem to the agent to admit of dissection, and he is likely to distinguish, in the case of any word of commendation or disapproval, between its 'moral sense' and 'non-moral senses'. Such a distinction is not as easy as it might seem even in the case of $a \gamma \alpha \theta$ ós, as we see from Pl. Rep. $379 a-c$. Plato there makes an argument turn on the inclusion of a good person (in this case, God) in the category of $\dot{\alpha} \gamma \alpha \theta \dot{\alpha}$. Beginning with the premise that God is $\alpha \gamma \alpha \theta$ ós, Socrates asserts

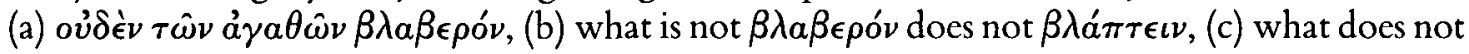

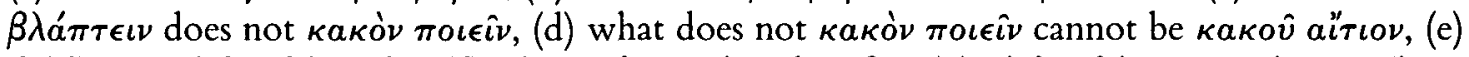

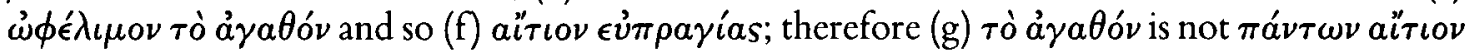

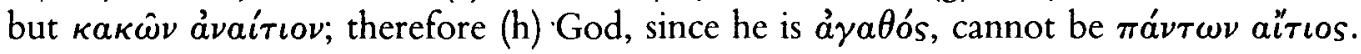

Plato is not playing tricks with us here. He is aware (indeed, the awareness is fundamental to his metaphysics) of the affinity between our response to a person who is $\kappa \alpha \kappa \hat{\omega} \nu$ ávaítıos and our response to nourishing food or fertile land; and aware, I think, that as an experience a response which even the most refined analysis would allow to be moral may be indistinguishable from an aesthetic reaction. Sloppy table manners can create more implacable enmities than pride or callousness; if we cause the death of a bird by accident, a pretty bird that sings is a more grievous burden on our conscience than an ugly bird that croaks; and 'nauseating' as a term of moral disapproval is not just a metaphor. ${ }^{28}$ The determinants of the moral values of an individual or a society are remarkably heterogeneous. That is why I stressed in GPM (e.g. I-4, 46 f.) the

${ }^{26}$ I find myself in essential agreement with Lesky (n. 13) 4I f. on Agamemnon's admissions and apologies, but where Lesky speaks of 'two sides of the same coin' I would prefer to speak of two coins which have the same nominal value but are acceptable social tender in different circumstances. $C f$. also Lloyd-Jones (n. 4) i $4 \mathrm{f}$.
27 The immensity of the gulf between the logic of morality and the experience of morality may be glimpsed in A. N. Prior, Papers on Time and Tense (Oxford I968) $5 \mathrm{I}-8$.

${ }^{28}$ I invite the reader to consider the reaction of his own stomach to the comment made in $M E R 237$ on the 
inconsistent, incoherent and unsystematic nature of Greek (or any other) popular morality. In criticising me for this Adkins (Problems I $47 \mathrm{f}$.) ${ }^{29}$ points out that 'a functional structure may exist in the absence of rational design' and that the grammar of a language is an example of systems which 'exhibit coherent structures in the absence of grammarians' (etc.) 'to design them'. I welcome this analogy, but employ it differently. The generalisations ('rules') which constitute a descriptive grammar of a language include some of very wide application, but a great number each one of which applies to a single word or to a group of words definable only by enumeration. Few rules cohere in the sense that one is predictable from another or explicable in the light of others. During the continuous process of change which characterises a living language, rules contract and extend their domains, some perish and others are born. The determinants of linguistic change, as of morality, are heterogeneous. The rules are not at any moment coherent or systematic to the extent which we expect of the product of deliberate, rational planning and deduction, and in speaking of human behaviour that is the standard of coherence and system which I apply. A comparable lack of coherence and system is apparent in moral, legal and religious codes; fervent adherence to the Fifth Commandment is not only logically compatible with total rejection of the Second, but compatible in practice, as much of human history shows.

In the work of ancient philosophers the distinction between moralising (i.e. telling us how we ought to behave) and moral philosophy (i.e. telling us how we ought to think about morality if we wish to avoid logical error) is harder to discern than in modern philosophical works, because the 'evangelical' ingredient in ancient philosophy is greater. This has a bearing on the question posed in the opening sentence of Problems (143), 'Do moral philosophers affect the values of nonphilosophers...?', and affects explanation of any changes which might be discerned in Greek morality during a given period. Moral change is most spectacularly determined by technological change; a new 'can' generates a tempting 'ought' and its consequences provoke a reflective 'ought not'. Less spectacularly, any completed action demonstrates a 'can' by virtue of being completed and so takes its place in the range of possible models available to any subsequent agent. That the utterances of philosophers might cause moral change is implied by Ar. Ra. I $49 \mathrm{I} \rightarrow 9$ (in conjunction with 905-I098), fr. 376, Telekleides frr. $39 \mathrm{f}$. We can understand why comic poets should say this, but we are not obliged to believe them. There is, however, no reason a priori why a dramatist should not exploit an idea which he has taken directly from a philosopher: that is to say, from the moralising element, intelligible and memorable without sustained intellectual effort on the part of the hearer or reader, in the work of someone whose distinctive contribution to ethics is rigorous argument not so casily understood and remembered. Equally, there is no reason why an idea expressed by an intellectual should not be widely disseminated (nescit vox missa reverti) and generate an innovation at popular level. ${ }^{30}$ The difficulty, for the historian of literature or of morality, is to decide when, if ever, that has actually happened. It will not do simply to treat the grumbles of characters in comedy or the polemic of intellectuals hostile to rhetoric (Problems 146) as evidence that Athenian forensic speakers actually used persuasive sophistical arguments which subverted popular values. Even in academic life I have heard perfectly clear expositions described as 'sophistical', 'laboured' or a 'rigmarole' by people who resented the conclusions to which the exposition pointed, and it is to be expected that old men in comedy will complain about 'clever' young men. In any case, the rhetorician did not teach his pupils how to override the jury's values but (like a modern barrister) how to exploit those values.

Athenians under the Thirty Tyrants: "The democracy squealed, as democracies will; but it is difficult to see what cause it had for complaint.'

${ }^{29} C f$. also Gould, $C R$ xxviii (1978) 287. The statement in Problems 148 about my view of the 'structure' of popular morality is incorrect, despite the verisimilitude imparted by inverted commas.
30 Problems I 44 confuses the classification popular/ sectional/idiosyncratic with the antithesis traditional/innovative. Problems I 45 debits me with an 'apparent' reason for citing (GPM IO-I3) references to philosophy in the orators which is not the same as the reason I actually gave ad loc. 
Moreover, a reflex of philosophical moralising is hardly to be distinguished from a reflex of didactic poetry, proverbs or oracular maxims - any of which may itself be the ancestor of a moralising passage in a philosophical work-or of a simple but penetrating idea suggested by a certain conjunction of circumstances and articulated by a political or forensic speaker or even a participant in a conversation. On Adkins' own premisses Theognis $147 \mathrm{f}$.

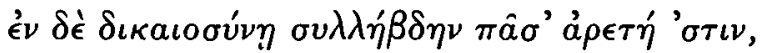

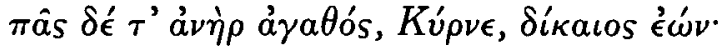

is a landmark in the history of Greek moral thinking: "suddenly . . . we find . . the amazing couplet'. Now, the authors of the Theognidea exercise, as a rule competently and on occasion excellently, ooфia in the sense which the word had in their day, but they are not 'philosophers', and I doubt whether we should class them as 'intellectuals', if we define ${ }^{\mathbf{3 1}}$ an intellectual as a person who enjoys (as many artists and creative writers do not) analytical investigation. It is not in the least necessary (pace $M E R$ 79) to imagine that Theognis $147 \mathrm{f}$. is the product of decp reflection. A didactic poet may be, so to speak, a character in the drama of his own life, and the couplet sounds like the cry of someone who thinks he has suffered intolerable injustice at the hands of a self-satisfied and generally admired adversary. Hesiod could have voiced the same sentiment at the time when he was composing parts of Works and Days; ${ }^{32}$ so could the Penelope of $\mathrm{Od}$. xxi $3 \mathrm{I} 2 \mathrm{ff}$. in the mood of the moment.

Adkins remarks (Problems I 56 n. 6) that I 'like modern parallels'. I do indeed, and grow daily fonder of them, in the confident belief that they help to remind us that the few Greeks whom we know through surviving literature are only samples drawn from a population whose days were as fully occupied by action and speech as ours. In part ii, ch. 2 of Piccolo Mondo Antico Fogazzaro makes Luisa utter a perceptive and unconventional view on why people believe in immortality, heaven and hell. I do not know whether Fogazzaro had any literary or philosophical 'source' for this view but I do recall hearing it expressed, less neatly but with no less conviction, by a semi-literate Italian countrywoman. Perhaps her words were a reflex, through many intermediarics over an eighty-year period, of Luisa's, but it is equally possible that they occurred independently to her and to Fogazzaro; possible, too, that Fogazzaro himself was drawing upon the rebellious ideas which surface from time to time in an ambience dominated by orthodox preaching. There is a certain analogy between such a case and Hecuba's subordination of the divine world to vómos in E. Hec. 798-805 or the deadly criticism of majority rule attributed to the youthful Alkibiades in X. Mem. i 2.45. Neither of those two arguments would have been appropriate or welcome in a speech delivered to a mass jury, and it would be contrary to the available evidençe to assign either of them to the broad stream of 'popular morality'; yet neither need be attributed to a cultural and intellectual stratum above the level of ordinary, intelligent speculation.

\section{Corpus Christi College,} Oxford

\section{K. J. Dover}

${ }^{31}$ Cf. n. 9 above.

${ }^{32}$ Cf. J. P. Vernant, Mythe et pensée chez les Grecs (Paris 1974), chs I-2, and Lloyd-Jones (n. 4) $32 \mathrm{f}$, $35 \mathrm{f}$. The cursory treatment of Hesiod in $M E R \quad 70-3$ concludes rather simply that 'Homeric society' and

\begin{abstract}
'Hesiodic society' are different societies. It would have been more interesting to consider the extent to which 'Homeric' and 'Hesiodic' evaluations could be uttered not only in the same society but even by the same individual in different circumstances.
\end{abstract}

